\title{
Stimulation of Erythrocyte Cell Membrane Scrambling by Mitotane
}

\author{
Janin Jacobia Elisabeth Lang ${ }^{\mathrm{a}}$ Rosi Bissinger ${ }^{\mathrm{a}}$ Leonie Frauenfeld ${ }^{\mathrm{a}}$ \\ Paola Modicano $^{\mathrm{b}}$ Caterina Faggio $^{\mathrm{b}}$ Majed Abed ${ }^{\mathrm{a}}$ Florian Lang ${ }^{\mathrm{a}}$
}

${ }^{a}$ Department of Physiology, University of Tuebingen, Tuebingen, Germany, ${ }^{b}$ Department of Biological and Environmental Sciences, University of Messina, S.Agata-Messina, Italy

\section{Key Words}

Phosphatidylserine $\cdot$ Ionomycin $•$ Calcium $•$ Cell volume $・$ Eryptosis

\begin{abstract}
Background: Mitotane (1,1-dichloro-2-[o-chlorophenyl]-2-[p-chlorophenyl]ethane), a cytostatic drug used for the treatment of adrenocortical carcinomas, is effective by triggering tumor cell apoptosis. In analogy to apoptosis of nucleated cells, eryptosis is the suicidal death of erythrocytes, which is typically paralleled by cell shrinkage and breakdown of cell membrane phosphatidylserine asymmetry with subsequent phosphatidylserine exposure at the erythrocyte surface. Eryptosis may be triggered by increase of cytosolic $\mathrm{Ca}^{2+}$ concentration $\left(\left[\mathrm{Ca}^{2+}\right]_{\mathrm{i}}\right)$. The present study tested, whether treatment of human erythrocytes with mitotane is followed by eryptosis. Methods: $\left[\mathrm{Ca}^{2+}\right]_{\mathrm{i}}$ was estimated from Fluo3 fluorescence, cell volume from forward scatter, phosphatidylserine exposure from annexin $\mathrm{V}$ binding, and hemolysis from hemoglobin release. Results: Exposure to mitotane $(\geq 5 \mu \mathrm{g} / \mathrm{ml} \approx 16 \mu \mathrm{M})$ significantly increased $\left[\mathrm{Ca}^{2+}\right]_{i^{\prime}}$ increased annexin $\mathrm{V}$ binding and triggered hemolysis, but did not significantly modify forward scatter. The effect on annexin $V$ binding was significantly blunted in the absence of extracellular $\mathrm{Ca}^{2+}$. Within $30 \mathrm{~min} \mathrm{Ca}^{2+}$ ionophore ionomycin $(1 \mu \mathrm{M})$ decreased forward scatter, an effect virtually abolished in the presence of mitotane $(15 \mu \mathrm{g} / \mathrm{ml})$. Conclusions: Mitotane increases $\left[\mathrm{Ca}^{2+}\right]_{i}$ with subsequent phosphatidylserine translocation. By the same token mitotane inhibits $\mathrm{Ca}^{2+}$ induced cell shrinkage.
\end{abstract}




\section{Introduction}

Mitotane (1,1-dichloro-2-[o-chlorophenyl]-2-[p-chlorophenyl]ethane) is the drug of choice for non-resectable and metastatic adrenocortical carcinoma, a rare malignancy with a 5-year survival of less than 50\% [1-3]. The substance is effective by triggering apoptosis of tumor cells [4-6], an effect attributed to caspase activation [4]. Potential side effects of mitotane include anemia $[7,8]$.

Similar to apoptosis of nucleated cells, erythrocytes may undergo eryptosis, the suicidal death of erythrocytes characterized by erythrocyte shrinkage and breakdown of phosphatidylserine (PS) asymmetry of the erythrocyte cell membrane [9]. Eryptosis is stimulated by increase of cytosolic $\mathrm{Ca}^{2+}$ concentration $\left(\left[\mathrm{Ca}^{2+}\right]_{\mathrm{i}}\right)$ resulting from $\mathrm{Ca}^{2+}$ entry through $\mathrm{Ca}^{2+}$ permeable cation channels [9]. Increased $\left[\mathrm{Ca}^{2+}\right]_{\mathrm{i}}$ activates $\mathrm{Ca}^{2+}$ sensitive $\mathrm{K}^{+}$ channels [10] resulting in $\mathrm{K}^{+}$efflux, hyperpolarization, $\mathrm{Cl}^{-}$efflux and thus cell shrinkage due to cellular efflux of $\mathrm{KCl}$ with osmotically obliged water [9]. Increased $\left[\mathrm{Ca}^{2+}\right]_{\mathrm{i}}$ further triggers phospholipid scrambling of the cell membrane with translocation of phosphatidylserine to the erythrocyte surface [11]. The $\mathrm{Ca}^{2+}$ sensitivity of eryptosis is augmented by ceramide [9]. Further stimulators of eryptosis include energy depletion [9] and caspase activation [9, 12, 13]. Signaling governing eryptosis further includes AMP activated kinase AMPK [9], cGMP dependent protein kinase [9], Janus activated kinase JAK3 [14], casein kinase [15, 16], p38 kinase [17], PAK2 kinase [18] as well as sorafenib [19] and sunitinib [20] sensitive kinases.

Eryptosis is triggered by a large number of xenobiotics $[9,20-46]$ and excessive eryptosis contributes to the pathophysiology of several diseases [9] including diabetes [9, 13, 47], renal insufficiency [9], hemolytic uremic syndrome [9], sepsis [9], malaria [9], sickle cell disease [9], Wilson's disease [9], iron deficiency [9], malignancy [48], phosphate depletion [9], and metabolic syndrome [42].

The present study explored whether treatment of human erythrocytes with mitotane influenced $\left[\mathrm{Ca}^{2+}\right]_{i}$, cell volume and phosphatidylserine abundance at the cell surface. As a result, mitotane significantly increased $\left[\mathrm{Ca}^{2+}\right]_{\mathrm{i}}$ and significantly enhanced the phosphatidylserine abundance at the erythrocyte surface but did not significantly decrease erythrocyte volume.

\section{Materials and Methods}

Erythrocytes, solutions and chemicals

Leukocyte depleted erythrocytes were kindly provided by the blood bank of the University of Tübingen. The study is approved by the ethics committee of the University of Tübingen (184/2003V). Erythrocytes were incubated in vitro at a hematocrit of $0.4 \%$ in Ringer solution containing (in mM) $125 \mathrm{NaCl}, 5 \mathrm{KCl}, 1 \mathrm{MgSO}_{4}$, $32 \mathrm{~N} 2$ hydroxyethylpiperazine $\mathrm{N} 2$ ethanesulfonic acid (HEPES), 5 glucose, $1 \mathrm{CaCl}_{2} ; \mathrm{pH} 7.4$ at $37^{\circ} \mathrm{C}$ for 24 and $48 \mathrm{~h}$. Where indicated, erythrocytes were exposed to mitotane (Sigma-Aldrich, Germany) at the indicated concentrations. The substance was solved in up to $1.5 \mu \mathrm{l} / \mathrm{ml}$ DMSO. In $\mathrm{Ca}^{2+}$ free Ringer solution, $1 \mathrm{mM} \mathrm{CaCl}_{2}$ was substituted by $1 \mathrm{mM}$ glycol bis(2 aminoethylether) N,N,N',N' tetraacetic acid (EGTA).

\section{FACS analysis of annexin $V$ binding and forward scatter}

After incubation under the respective experimental condition, $50 \mu \mathrm{l}$ cell suspension was centrifuged ( $3 \mathrm{~min}$, $1600 \mathrm{rpm}, 23^{\circ} \mathrm{C}$ ). Ringer solution containing $5 \mathrm{mM} \mathrm{CaCl}_{2}$ was added to the erythrocytes and then stained with Annexin V FITC (1:200 dilution; ImmunoTools, Friesoythe, Germany) in this solution at $37^{\circ} \mathrm{C}$ for 20 min under protection from light. In the following, the forward scatter (FSC) of the cells was determined, i.e. the scatter of the light in line with the light beam. The FSC is a function of cell volume [49]. Annexin V fluorescence intensity was measured at an excitation wavelength of $488 \mathrm{~nm}$ and an emission wavelength of $530 \mathrm{~nm}$ on a FACS Calibur (BD, Heidelberg, Germany).

Measurement of intracellular $\mathrm{Ca}^{2+}$

After incubation $50 \mu \mathrm{l}$ cell suspension was centrifuged ( $3 \mathrm{~min}, 1600 \mathrm{rpm}, 23^{\circ} \mathrm{C}$ ). Erythrocytes were loaded with Fluo 3/AM (Biotium, Hayward, USA) in Ringer solution containing $5 \mathrm{mM} \mathrm{CaCl}_{2}$ and $2 \mu \mathrm{M}$ Fluo 


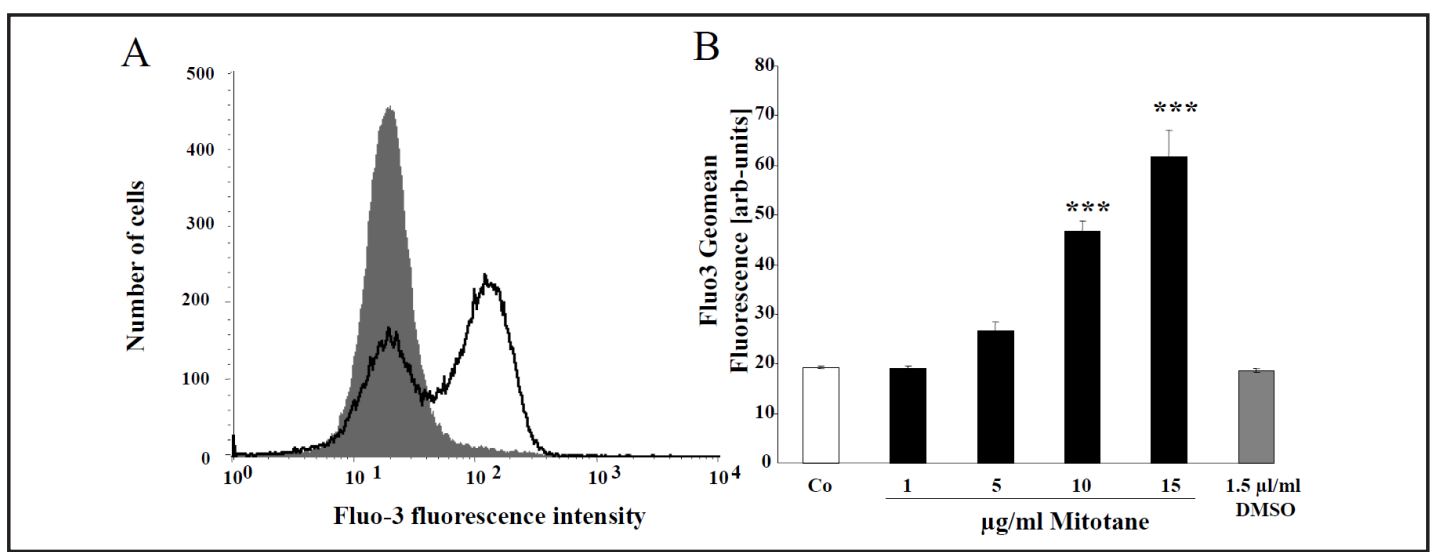

Fig. 1. Effect of mitotane on erythrocyte cytosolic $\mathrm{Ca}^{2+}$ concentration. A. Original histogram of Fluo3 fluorescence in erythrocytes following exposure for $24 \mathrm{~h}$ to Ringer solution without (grey shadow) and with (black line) presence of $15 \mu \mathrm{g} / \mathrm{ml}$ mitotane. B. Arithmetic means \pm SEM $(n=5)$ of the Fluo3 fluorescence (arbitrary units) in erythrocytes exposed for $24 \mathrm{~h}$ to Ringer solution without (white bar) or with mitotane $\left(1-15 \mu \mathrm{g} / \mathrm{ml}\right.$, black bars) or the solvent DMSO $(1.5 \mu \mathrm{l} / \mathrm{ml}$, grey bars $) .{ }^{* * *}(\mathrm{p}<0.001)$ indicate significant difference from the absence of mitotane (ANOVA).

3/AM. The cells were incubated at $37^{\circ} \mathrm{C}$ for $30 \mathrm{~min}$ and washed in Ringer solution containing $5 \mathrm{mM} \mathrm{CaCl}_{2}$. The Fluo 3/AM loaded erythrocytes were resuspended in $200 \mu \mathrm{l}$ Ringer. Then, $\mathrm{Ca}^{2+}$ dependent fluorescence intensity was measured at an excitation wavelength of $488 \mathrm{~nm}$ and an emission wavelength of $530 \mathrm{~nm}$ on a FACS Calibur (BD, Heidelberg, Germany).

\section{Measurement of hemolysis}

For the determination of hemolysis the samples were centrifuged ( $3 \mathrm{~min}$ at $400 \mathrm{~g}$, room temperature) after incubation, and the supernatants were harvested. As a measure of hemolysis, the hemoglobin (Hb) concentration of the supernatant was determined photometrically at $405 \mathrm{~nm}$. The absorption of the supernatant of erythrocytes lysed in distilled water was defined as $100 \%$ hemolysis.

\section{Statistics}

Data are expressed as arithmetic means \pm SEM. As indicated in the figure legends, statistical analysis was made using ANOVA with Tukey's test as post test and $t$ test as appropriate. $\mathrm{n}$ denotes the number of different erythrocyte specimens studied. Since different erythrocyte specimens used in distinct experiments are differently susceptible to triggers of eryptosis, the same erythrocyte specimens have been used for control and experimental conditions.

\section{Results}

The present study explored whether mitotane stimulates eryptosis, the suicidal death of erythrocytes. Stimulators of eryptosis include increase of cytosolic $\mathrm{Ca}^{2+}$ concentration $\left(\left[\mathrm{Ca}^{2+}\right]_{\mathrm{i}}\right)$. Accordingly, the effect of mitotane on $\left[\mathrm{Ca}^{2+}\right]_{\mathrm{i}}$ has been estimated utilizing Fluo3 fluorescence. Erythrocytes were incubated in Ringer solution without or with mitotane (1- $15 \mu \mathrm{g} / \mathrm{ml})$, loaded with Fluo3 AM and Fluo3 fluorescence quantified by FACS analysis. As shown in Fig. 1, a 24 hours exposure of human erythrocytes to mitotane resulted in an increase of Fluo3 fluorescence, an effect reaching statistical significance at $10 \mu \mathrm{g} / \mathrm{ml}$ mitotane concentration. Thus, mitotane treatment was followed by increase of $\left[\mathrm{Ca}^{2+}\right]_{\mathrm{i}}$ in human erythrocytes. Close inspection of the histogram reveals that mitotane increases Fluo3 fluorescence in the major portion of erythrocytes but does not modify Fluo3 fluorescence in a minor portion of the erythrocytes. As a result, the histogram shows two peaks of Fluo3 fluorescence in erythrocytes following mitotane treatment. 


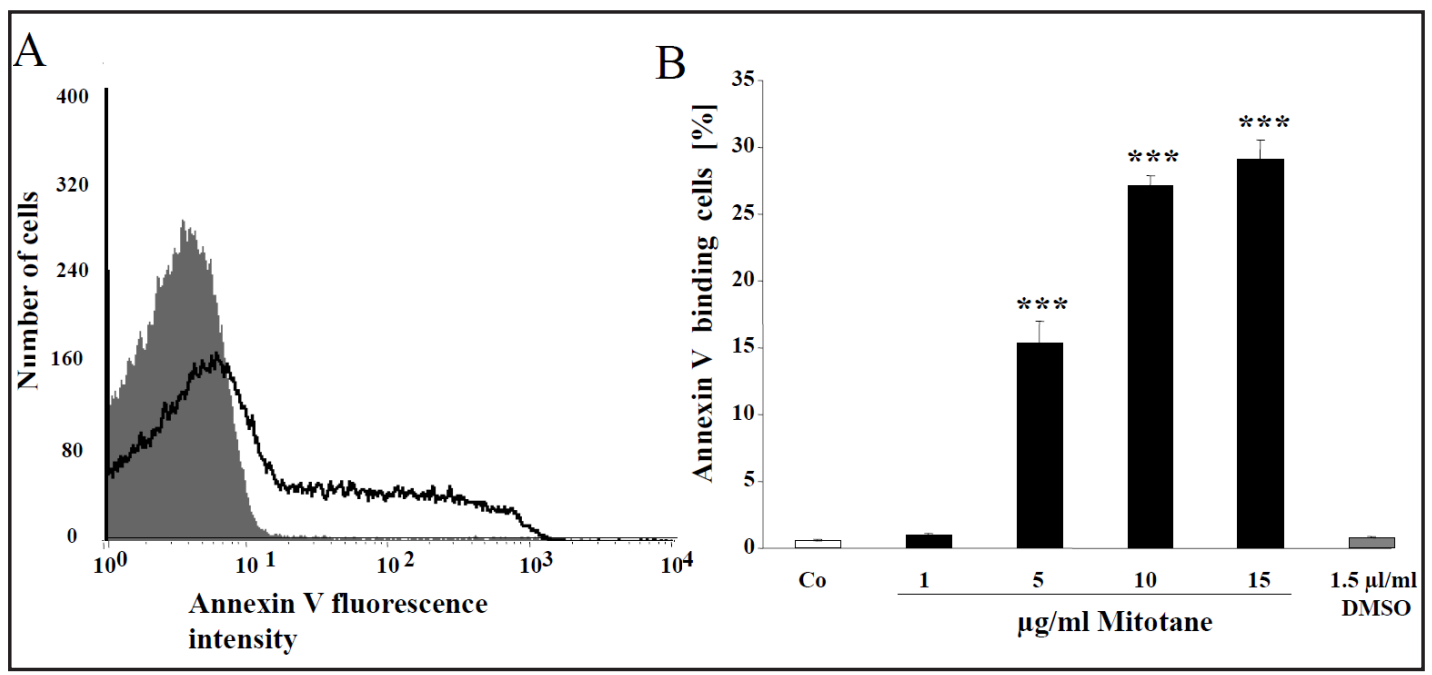

Fig. 2. Effect of mitotane on phosphatidylserine exposure. A. Original histogram of annexin $\mathrm{V}$ binding of erythrocytes following exposure for $24 \mathrm{~h}$ to Ringer solution without (grey shadow) and with (black line) presence of $15 \mu \mathrm{g} / \mathrm{ml}$ mitotane. B. Arithmetic means \pm SEM $(n=5)$ of erythrocyte annexin V binding following incubation for $24 \mathrm{~h}$ to Ringer solution without (white bar) or with mitotane ( $1-15 \mu \mathrm{g} / \mathrm{ml}$, black bars) or the solvent DMSO $(1.5 \mu \mathrm{l} / \mathrm{ml}$, grey bars $) .{ }^{* *}(\mathrm{p}<0.001)$ indicate significant differences from the absence of mitotane (ANOVA).

Fig. 3. Effect of $\mathrm{Ca}^{2+}$ withdrawal and addition of EGTA on mitotane induced annexin $\mathrm{V}$ binding. Arithmetic means \pm SEM $(n=6)$ of the percentage of annexin $\mathrm{V}$ binding erythrocytes after a $24 \mathrm{~h}$ treatment with Ringer solution without (white bars) or with mitotane $(15 \mu \mathrm{g} / \mathrm{ml}$ black bars) in the presence of $\mathrm{Ca}^{2+}$ ( left bars) or absence of $\mathrm{Ca}^{2+}$ in the absence (middle bars) and presence (right bars) of 1 mM EGTA. * $(\mathrm{p}<0.05),{ }^{* * *}(\mathrm{p}<0.001)$ indicate significant difference from the absence of mitotane (ANOVA), $\# \# \#(p<0.001)$ indicates significant difference from the respective values in the presence of $\mathrm{Ca}^{2+}$.

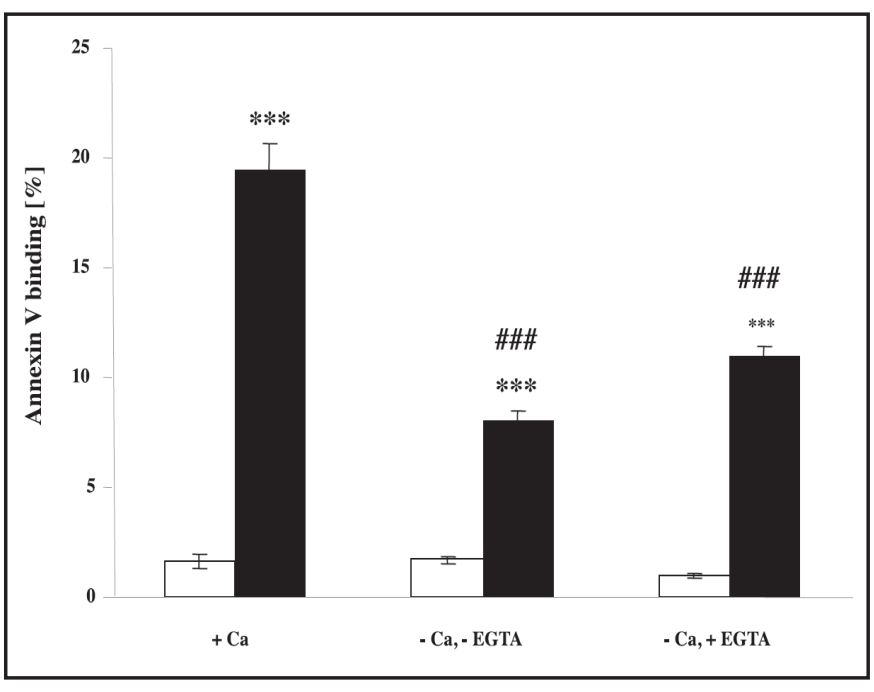

An increase of $\left[\mathrm{Ca}^{2+}\right]_{\mathrm{i}}$ has previously been shown to trigger cell membrane scrambling with appearance of phosphatidsylserine at the cell surface. To identify phosphatidylserine exposing erythrocytes, phosphatidylserine abundance at the cell surface was estimated utilizing FITC-labelled annexin V, which was detected in FACS analysis. As illustrated in Fig. 2, a 24 hours mitotane treatment increased the percentage of annexin $V$ binding erythrocytes, an effect reaching statistical significance at $5 \mu \mathrm{g} / \mathrm{ml}$ mitotane concentration. Thus, mitotane treatment triggered erythrocyte cell membrane scrambling.

Additional experiments explored whether the cell membrane scrambling following mitotane treatment was in part or fully dependent on $\mathrm{Ca}^{2+}$ entry from the extracellular space. Erythrocytes were exposed to $1-15 \mu \mathrm{g} / \mathrm{ml}$ mitotane for 24 hours in either the presence of 1 mM extracellular $\mathrm{Ca}^{2+}$ or in the absence of extracellular $\mathrm{Ca}^{2+}$ with either presence or absence of the $\mathrm{Ca}^{2+}$ chelator EGTA $(1 \mathrm{mM})$. Following mitotane treatment $(15 \mu \mathrm{g} / \mathrm{ml})$, Fluo3 fluorescence reflecting $\left[\mathrm{Ca}^{2+}\right]_{\mathrm{i}}$ increased from $19.4 \pm 0.7$ to $29.5 \pm 2.1$ arbitrary units $(\mathrm{n}=5)$ in the presence of extracellular $\mathrm{Ca}^{2+}$ but was in the absence of extracellular $\mathrm{Ca}^{2+}$ not significantly different 
Fig. 4. Effect of $\mathrm{K}^{+}$channel inhibitor clotrimazole, of antioxidant $\mathrm{N}$-acetylcysteine and of pancaspase inhibitor zVAD on mitotane induced annexin $\mathrm{V}$ binding. Arithmetic means \pm SEM ( $\mathrm{n}=$ 6 ) of the percentage of annexin $V$ binding erythrocytes after a $24 \mathrm{~h}$ treatment with Ringer solution without (white bars) or with $15 \mu \mathrm{g} / \mathrm{ml}$ mitotane (black bars) in the absence (A) or presence of $1 \mathrm{mM} \mathrm{N}$-acetyl-cysteine (B), of $5 \mu \mathrm{M}$ clotrimazole (C), or of $10 \mu \mathrm{M}$ zVAD (D), respectively.*** $(\mathrm{p}<0.001)$ indicate significant difference from the absence of mitotane (ANOVA).
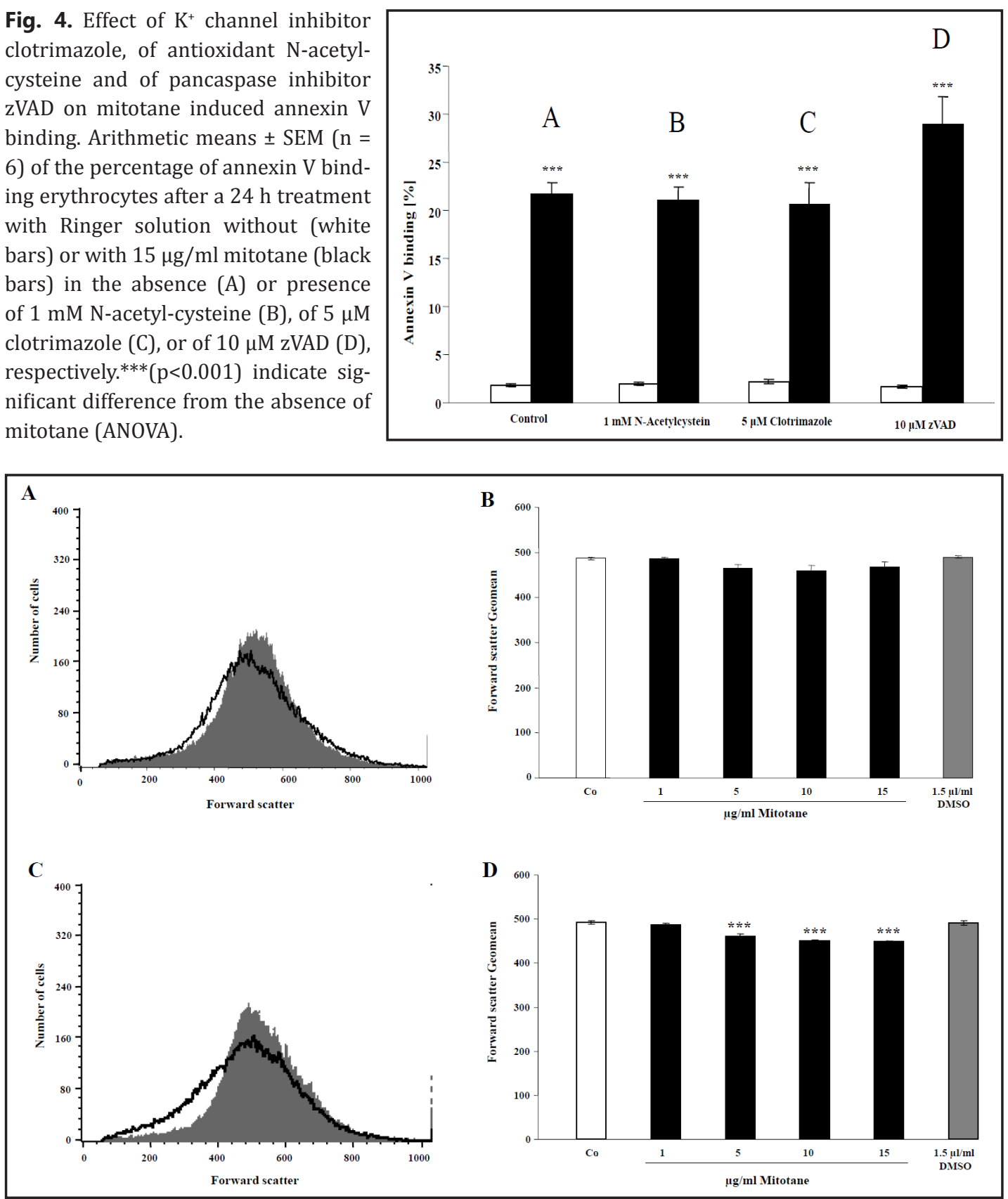

Fig. 5. Effect of mitotane on erythrocyte forward scatter. A. Original histogram of forward scatter of erythrocytes following exposure for $24 \mathrm{~h}$ to Ringer solution without (grey shadow) and with (black line) presence of $15 \mu \mathrm{g} / \mathrm{ml}$ mitotane. B. Arithmetic means \pm SEM $(n=5)$ of the normalized erythrocyte forward scatter (FSC) following exposure for $24 \mathrm{~h}$ to Ringer solution without (white bar) or with mitotane $(1-15 \mu \mathrm{g} / \mathrm{ml}$, black bars) or the solvent DMSO $(1.5 \mu \mathrm{l} / \mathrm{ml}$, grey bars). C. Original histogram of forward scatter of erythrocytes following exposure for $48 \mathrm{~h}$ to Ringer solution without (grey shadow) and with (black line) presence of $15 \mu \mathrm{g} / \mathrm{ml}$ mitotane. D. Arithmetic means \pm SEM $(n=5)$ of the normalized erythrocyte forward scatter (FSC) following exposure for $48 \mathrm{~h}$ to Ringer solution without (white bar) or with mitotane $(1-15 \mu \mathrm{g} / \mathrm{ml}$, black bars) or the solvent DMSO $(1.5 \mu \mathrm{l} / \mathrm{ml}$, grey bars $) .{ }^{* * *}(\mathrm{p}<0.001)$ indicate significant difference from the absence of mitotane (ANOVA).

between untreated (20.0 \pm 0.9 arbitrary units, $\mathrm{n}=5)$ and mitotane $(15 \mu \mathrm{g} / \mathrm{ml})$ treated $(24.3$ \pm 0.2 arbitrary units $(n=5)$ erythrocytes. As illustrated in Fig. 3 , removal of extracellular 
Fig. 6. Effect of $\mathrm{Ca}^{2+}$ ionophore ionomycin on forward scatter in the absence and presence of mitotane. Arithmetic means \pm SEM $(n=4)$ of the normalized erythrocyte forward scatter (FSC) after a 1 hour treatment with Ringer solution without (white bars) or with $15 \mu \mathrm{g} / \mathrm{ml}$ mitotane (black bars) in the absence (left bars) or in the presence of $1 \mu \mathrm{M}$ ionomycin (right bars). ${ }^{* * *}(\mathrm{p}<0.001)$ indicate significant difference from the absence of ionomycin (ANOVA), $\# \# \#(p<0.001)$ indicates significant difference from the respective values in the absence of mitotane.

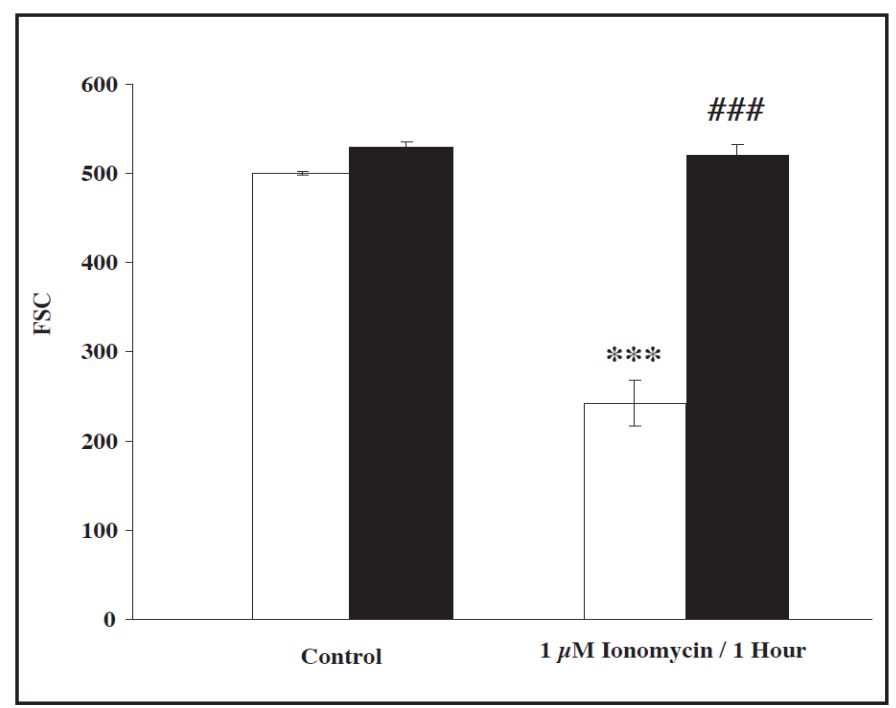

$\mathrm{Ca}^{2+}$ significantly blunted the effect of mitotane on annexin $\mathrm{V}$ binding irrespective of the presence or absence of EGTA. However, even in the nominal absence of extracellular $\mathrm{Ca}^{2+}$ the percentage annexin $\mathrm{V}$ binding erythrocytes was still significantly increased by mitotane treatment (Fig. 3). Accordingly, the effect of mitotane on cell membrane scambling was in part but not fully dependent on the presence of extracellular $\mathrm{Ca}^{2+}$.

In search for additional mechanisms triggering cell membrane scrambling following mitotane treatment of erythrocytes, mitotane was applied in the presence and absence of $\mathrm{K}^{+}$channel blocker clotrimazole, of caspase inhibitor zVAD and of antioxidant $\mathrm{N}$-acetylcystein. As illustrated in Fig. 4, mitotane treatment increased the percentage of annexin V binding cells to a similar extent in the absence and presence of $\mathrm{N}$-acetyl-cysteine $(1 \mathrm{mM})$, clotrimazole $(5 \mu \mathrm{M})$ or of zVAD $(10 \mu \mathrm{M})$. The percentage of annexin V binding cells following treatment with mitotane even tended to be higher in the prescence than in the absence of zVAD (Fig. 4), a difference, however, not reaching statistical significance. Clotrimazole has previously been shown to inhibit lead induced eryptosis [50] and $\mathrm{N}$-acetyl-cysteine has previously been shown to inhibit Bay 11-7082 and parthenolide induced eryptosis [28]. Additional experiments were performed to test whether zVAD $(10 \mu \mathrm{M})$ was effective in another type of eryptosis. To this end erythrocytes were exposed for 48 hours to Ringer or eryptosis inducing kinase inhibitor sunitinib [20] with or without the additional presence of zVAD. As a result, sunitinib $(20 \mu \mathrm{M})$ increased the percentage annexin $V$ binding cells from $1.5 \pm 0.2$ to $37.5 \pm 3.4 \%(n=6)$ in the absence and from $1.3 \pm 0.3$ to $21.7 \pm 4.3 \%(n=6)$ in the presence of zVAD $(10 \mu \mathrm{M})$. Thus, zVAD blunted the sunitinib induced eryptosis.

An increase of $\left[\mathrm{Ca}^{2+}\right]_{\mathrm{i}}$ is further expected to activate $\mathrm{Ca}^{2+}$ sensitive $\mathrm{K}^{+}$channels leading to cellular efflux of $\mathrm{KCl}$ together with osmotically obliged water and thus to cell shrinkage. In order to estimate erythrocyte volume, forward scatter was determined in FACS analysis. As illustrated in Fig. 5, mitotane treatment tended to decrease forward scatter within 24 hours and significantly decreased forward scatter within 48 hours.

The lack of erythrocyte shrinkage despite the increase of $\left[\mathrm{Ca}^{2+}\right]_{\mathrm{i}}$ may have resulted from an inhibitory effect of mitotane on the $\mathrm{Ca}^{2+}$ sensitive $\mathrm{K}^{+}$channels and/or the $\mathrm{Cl}^{-}$channels required for the parallel $\mathrm{Cl}^{-}$efflux. If mitotane was inhibiting those channels, then mitotane treatment would interfere with the erythrocyte shrinkage following increase of $\left[\mathrm{Ca}^{2+}\right]_{\mathrm{i}}$ upon treatment of erythrocytes with the $\mathrm{Ca}^{2+}$ ionophore ionomycin. Thus, forward scatter was determined prior to and 30 minutes following treatment with $1 \mu \mathrm{M}$ ionomycin in the presence and absence of mitotane. Ionomycin increased the Fluo3 fluorescence reflecting $\left[\mathrm{Ca}^{2+}\right]_{\mathrm{i}}$ from $20.4 \pm 0.2_{-}$to $75.6 \pm 6.4$ arbitrary units $(\mathrm{n}=5)$ in the absence of mitotane and from $25.1 \pm 2.7$ to $110.3 \pm 6.6$ arbitrary units $(n=5)$ in the presence of mitotane $(15 \mu \mathrm{g} / \mathrm{ml})$. 
Fig. 7. Effect of short mitotane exposure on annexin $\mathrm{V}$ binding and hemolysis. Arithmetic means \pm SEM $(n=5)$ of the percentage of annexin $\mathrm{V}$ binding (black bars) or hemolysed (grey bars) erythrocytes following incubation for 2.5 hours to Ringer solution without ( $\mathrm{Co}=$ control) or with mitotane (5 - $10 \mu \mathrm{g} / \mathrm{ml}$ ) or the solvent DMSO (1.5 $\mu \mathrm{l} / \mathrm{ml}$, right bars). $* * *(\mathrm{p}<0.001)$ indicate significant differences from the absence of mitotane (ANOVA).

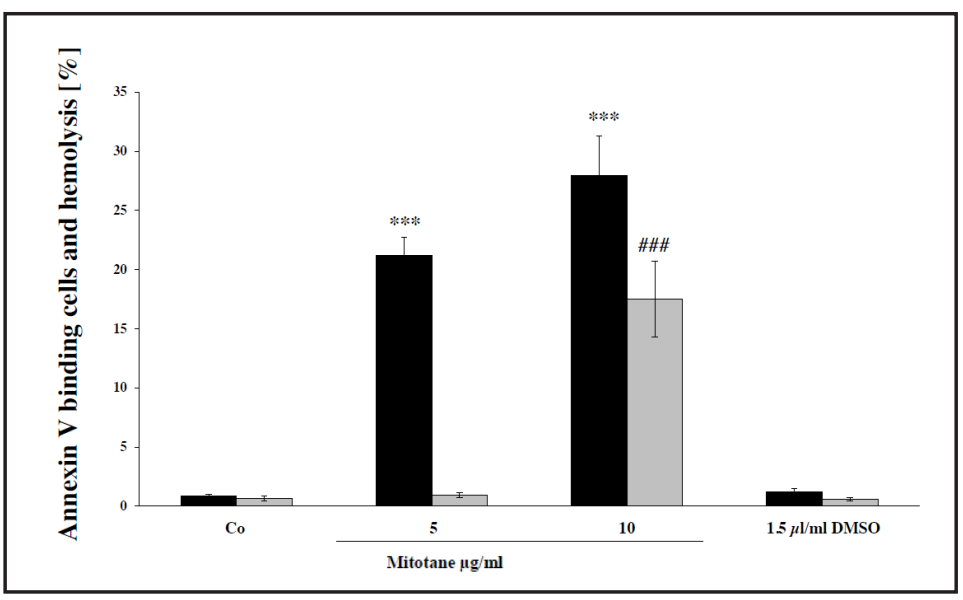

As shown in Fig. 6 ionomycin treatment was followed by a sharp decrease of forward scatter in the absence, but not in the presence of mitotane $(15 \mu \mathrm{g} / \mathrm{ml})$.

The inability of mitotane treated erythrocytes to decrease their volume upon increase of $\left[\mathrm{Ca}^{2+}\right]_{\mathrm{i}}$ may enhance their susceptibility to hemolysis. As illustrated in Fig. 7, the percentage of hemolysed erythrocytes was low following treatment of erythrocytes for 2.5 hours with 5 $\mu \mathrm{g} / \mathrm{ml}$ mitotane but increased to almost the same value following a 2.5 hours treatment with $10 \mu \mathrm{g} / \mathrm{ml}$ mitotane. Following a 24 hours exposure to mitotane the percentage of hemolysed erythrocytes amounted to ( $\mathrm{n}=5 \mathrm{each}$ ) $0.5 \pm 0.2 \%$ (absence of mitotane), $0.4 \pm 0.2 \%$ (at 1 $\mu \mathrm{g} / \mathrm{ml}$ mitotane), $20.0 \pm 2.6 \%$ (at $5 \mu \mathrm{g} / \mathrm{ml}$ mitotane), $56.7 \pm 2.5 \%$ (at $10 \mu \mathrm{g} / \mathrm{ml}$ mitotane) and $62.8 \pm 2.8 \%$ (at $15 \mu \mathrm{g} / \mathrm{ml}$ mitotane). The hemolysis reached statistical significance at 5 $\mu \mathrm{g} / \mathrm{ml}$ mitotane concentration.

\section{Discussion}

The present study reveals that mitotane triggers cell membrane scrambling of erythrocytes. Mitotane treatment of erythrocytes drawn from healthy volunteers is followed by breakdown of phosphatidylserine asymmetry of the cell membrane, a hallmark of eryptosis. The concentrations required to stimulate eryptosis are in the range of the reported therapeutic threshold concentrations of $14-20 \mu \mathrm{g} / \mathrm{ml}$ and still below toxic mitotane concentrations exceeding $30 \mu \mathrm{g} / \mathrm{ml}$ [51].

The breakdown of phosphatidylserine asymmetry of the erythrocyte cell membrane following mitotane treatment was presumably in part due to an increase of cytosolic $\mathrm{Ca}^{2+}$ concentration $\left(\left[\mathrm{Ca}^{2+}\right]_{\mathrm{i}}\right)$. The phosphatidylserine abundance at the surface of mitotane treated erythrocytes was significantly blunted in the absence of extracellular $\mathrm{Ca}^{2+}$. An increase of $\left[\mathrm{Ca}^{2+}\right]_{\mathrm{i}}$ is well known to stimulate cell membrane scrambling with phosphatidylserine translocation from the inner leaflet of the cell membrane to the outer leaflet of the cell membrane [9]. The channels mediating $\mathrm{Ca}^{2+}$ entry are $\mathrm{Ca}^{2+}$ permeable non selective cation channels involving the transient receptor potential channel TRPC6 [9]. The $\mathrm{Ca}^{2+}$ permeable erythrocyte cation channels are stimulated by oxidative stress [9]. The lacking inhibitory effect of antioxidant $\mathrm{N}$-acetyl-cystein suggests, however, that mitotane does not activate the channels by inducing oxidatitve stress.

Notably, a minor portion of erythrocytes appears to maintain the Fluo3 fluorescence following mitotane treatment, a result pointing to heterogeneity in mitotane sensitivity of the erythrocyte population. Earlier experiments revealed that sensitivity to triggers of eryptosis may be affected by erythrocyte age [27].

The mitotane sensitivity of $\left[\mathrm{Ca}^{2+}\right]_{\mathrm{i}}$ and the blunted effect of mitotane on annexin $\mathrm{V}$ binding in the absence of extracellular $\mathrm{Ca}^{2+}$ clearly indicate that mitotane is at least partially 
effective by triggering $\mathrm{Ca}^{2+}$ entry. The search for further mechanisms involved were not successful. Mitotane induced eryptosis was not significantly modified by $\mathrm{K}^{+}$channel blocker clotrimazole, antioxidant $\mathrm{N}$-acetyl-cysteine and caspase inhibitor zVAD. Thus, the effect of mitotane does apparently not require activation of $\mathrm{K}^{+}$channels, oxidative stress or activation of caspases. In theory, mitotane could influence some of the kinases participating in the regulation of eryptosis, such as AMPK [9], G kinase [9], JAK3 [14], casein kinase [15, 16], p38 kinase [17], PAK2 kinase [18] or sorafenib [19] and sunitinib [20] sensitive kinases. In any case, the effect of mitotane on cell membrane scrambling is in large part due to $\mathrm{Ca}^{2+}$ entry.

An increase of $\left[\mathrm{Ca}^{2+}\right]_{i}$ was expected to activate $\mathrm{Ca}^{2+}$ sensitive $\mathrm{K}^{+}$channels $[10,52]$ leading to cell membrane hyperpolarization. The increased electrical driving force was expected to drive $\mathrm{Cl}^{-}$efflux with cellular efflux of $\mathrm{KCl}$ and osmotically obliged water thus resulting in erythrocyte shrinkage [9]. However, despite the increase of $\left[\mathrm{Ca}^{2+}\right]_{\mathrm{i}}$, mitotane treatment was not followed by appreciable cell shrinkage. Moreover, mitotane abrogated the cell shrinkage following increase of $\left[\mathrm{Ca}^{2+}\right]_{i}$ with $\mathrm{Ca}^{2+}$ ionophore ionomycin. Presumably, mitotane inhibits the $\mathrm{Ca}^{2+}$ sensitive $\mathrm{K}^{+}$channels and/or the $\mathrm{Cl}^{-}$channels in the erythrocyte cell membane. Entry of $\mathrm{Na}^{+}$through the unselective cation channels and simultaneous inhibition of $\mathrm{Ca}^{2+}$ sensitive $\mathrm{K}^{+}$channels may foster cell swelling, which could eventually result in disruption of the erythrocyte membrane and thus hemolysis.

The stimulation of cell membrane scrambling by mitotane may lead to anemia. Phosphatidylserine exposing erythrocytes are rapidly removed from circulating blood [9]. If the clearance of phosphatidylserine exposing erythrocytes is not matched by formation of new erythrocytes, anemia develops [9]. Knowledge about the effect of mitotane on anemia is scarce [7, 8]. It must be kept in mind, that the drug is used in malignancy [1-3], a disorder causing anemia [53]. Thus, during mitotane treatment the eryptotic effects of mitotane may be outweighed by the effects of decreasing tumor mass.

Phosphatidylserine exposing erythrocytes may further bind to endothelial CXCL16/ SR PSO [54] and adhere to the vascular wall thus compromizing microcirculation [5459]. Phosphatidylserine exposure further fosters blood clotting and thus predisposes to development of thrombosis [55, 60, 61].

In conclusion, exposure of human erythrocytes to mitotane triggers $\mathrm{Ca}^{2+}$ entry with subsequent stimulation of cell membrane scrambling. Mitotane does, however, not decrease cell volume.

\section{Acknowledgements}

The authors acknowledge the meticulous preparation of the manuscript by Ali Soleimanpour. This study was supported by the Deutsche Forschungsgemeinschaft and Open Access Publishing Fund of Tuebingen University.

\section{Disclosure Statement}

The authors declare that they have no potential conflict of interest.

\section{References}

1 De Francia S, Ardito A, Daffara F, Zaggia B, Germano A, Berruti A, Di Carlo F: Mitotane treatment for adrenocortical carcinoma: an overview. Minerva Endocrinol 2012;37:9-23.

2 Garg MB, Sakoff JA, Ackland SP: A simple HPLC method for plasma level monitoring of mitotane and its two main metabolites in adrenocortical cancer patients. J Chromatogr B Analyt Technol Biomed Life Sci 2011;879:2201-2205. 
3 Kirschner LS: The next generation of therapies for adrenocortical cancers. Trends Endocrinol Metab 2012;23:343-350.

4 Lehmann TP, Wrzesinski T, Jagodzinski PP: The effect of mitotane on viability, steroidogenesis and gene expression in NCIH295R adrenocortical cells. Mol Med Rep 2013;7:893-900.

5 Zatelli MC, Gentilin E, Daffara F, Tagliati F, Reimondo G, Carandina G, Ambrosio MR, Terzolo M, Degli Uberti EC: Therapeutic concentrations of mitotane (o,p'-DDD) inhibit thyrotroph cell viability and TSH expression and secretion in a mouse cell line model. Endocrinology 2010;151:2453-2461.

6 Pushkarev VM, Tronko ND, Kostyuchenko NN, Mikosha AS: Effect of o,p'-DDD and Li+ on apoptotic DNA fragmentation in conventionally normal and tumour tissues of human adrenal cortex. Ukr Biokhim Zh 2007;79:44-49. Kaufman J: Diseases of the adrenal cortex of dogs and cats. Mod Vet Pract 1984;65:513-516. Weiss DJ: Bone marrow necrosis in dogs: 34 cases (1996-2004). J Am Vet Med Assoc 2005;227:263-267. Lang E, Qadri SM, Lang F: Killing me softly - suicidal erythrocyte death. Int J Biochem Cell Biol 2012;44:1236-1243.

10 Brugnara C, de Franceschi L, Alper SL: Inhibition of $\mathrm{Ca}(2+)$-dependent $\mathrm{K}+$ transport and cell dehydration in sickle erythrocytes by clotrimazole and other imidazole derivatives. J Clin Invest 1993;92:520-526.

11 Berg CP, Engels IH, Rothbart A, Lauber K, Renz A, Schlosser SF, Schulze-Osthoff K, Wesselborg S: Human mature red blood cells express caspase- 3 and caspase-8, but are devoid of mitochondrial regulators of apoptosis. Cell Death Differ 2001;8:1197-1206.

12 Lau IP, Chen H, Wang J, Ong HC, Leung KC, Ho HP, Kong SK: In vitro effect of CTAB- and PEG-coated gold nanorods on the induction of eryptosis/erythroptosis in human erythrocytes. Nanotoxicology 2012;6:847856.

13 Maellaro E, Leoncini S, Moretti D, Del Bello B, Tanganelli I, De Felice C, Ciccoli L: Erythrocyte caspase-3 activation and oxidative imbalance in erythrocytes and in plasma of type 2 diabetic patients. Acta Diabetol 2013;50:489-495.

14 Bhavsar SK, Gu S, Bobbala D, Lang F: Janus kinase 3 is expressed in erythrocytes, phosphorylated upon energy depletion and involved in the regulation of suicidal erythrocyte death. Cell Physiol Biochem 2011;27:547-556.

15 Kucherenko Y, Zelenak C, Eberhard M, Qadri SM, Lang F: Effect of casein kinase 1alpha activator pyrvinium pamoate on erythrocyte ion channels. Cell Physiol Biochem 2012;30:407-417.

-16 Zelenak C, Eberhard M, Jilani K, Qadri SM, Macek B, Lang F: Protein kinase CK1alpha regulates erythrocyte survival. Cell Physiol Biochem 2012;29:171-180.

17 Gatidis S, Zelenak C, Fajol A, Lang E, Jilani K, Michael D, Qadri SM, Lang F: p38 MAPK activation and function following osmotic shock of erythrocytes. Cell Physiol Biochem 2011;28:1279-1286.

18 Zelenak C, Foller M, Velic A, Krug K, Qadri SM, Viollet B, Lang F, Macek B: Proteome analysis of erythrocytes lacking AMP-activated protein kinase reveals a role of PAK2 kinase in eryptosis. J Proteome Res 2011;10:1690-1697.

19 Lupescu A, Shaik N, Jilani K, Zelenak C, Lang E, Pasham V, Zbidah M, Plate A, Bitzer M, Foller M, Qadri SM, Lang F: Enhanced Erythrocyte Membrane Exposure of Phosphatidylserine Following Sorafenib Treatment: An in vivo and in vitro Study. Cell Physiol Biochem 2012;30:876-888.

-20 Shaik N, Lupescu A, Lang F: Sunitinib-sensitive suicidal erythrocyte death. Cell Physiol Biochem 2012;30:512-522.

21 Abed M, Towhid ST, Mia S, Pakladok T, Alesutan I, Borst O, Gawaz M, Gulbins E, Lang F: Sphingomyelinaseinduced adhesion of eryptotic erythrocytes to endothelial cells. Am J Physiol Cell Physiol 2012;303:C991999.

-22 Bottger E, Multhoff G, Kun JF, Esen M: Plasmodium falciparum-infected erythrocytes induce granzyme B by NK cells through expression of host-Hsp70. PLoS One 2012;7:e33774.

23 Felder KM, Hoelzle K, Ritzmann M, Kilchling T, Schiele D, Heinritzi K, Groebel K, Hoelzle LE: Hemotrophic mycoplasmas induce programmed cell death in red blood cells. Cell Physiol Biochem 2011;27:557-564.

24 Firat U, Kaya S, Cim A, Buyukbayram H, Gokalp O, Dal MS, Tamer MN: Increased caspase-3 immunoreactivity of erythrocytes in STZ diabetic rats. Exp Diabetes Res 2012;2012:316384.

25 Ganesan S, Chaurasiya ND, Sahu R, Walker LA, Tekwani BL: Understanding the mechanisms for metabolism-linked hemolytic toxicity of primaquine against glucose 6-phosphate dehydrogenase deficient human erythrocytes: evaluation of eryptotic pathway. Toxicology 2012;294:54-60. 
Jacobi et al.: Mitotane Induced Eryptosis

26 Gao M, Cheung KL, Lau IP, Yu WS, Fung KP, Yu B, Loo JF, Kong SK: Polyphyllin D induces apoptosis in human erythrocytes through $\mathrm{Ca}(2)(+)$ rise and membrane permeabilization. Arch Toxicol 2012;86:741-752.

27 Ghashghaeinia M, Cluitmans JC, Akel A, Dreischer P, Toulany M, Koberle M, Skabytska Y, Saki M, Biedermann T, Duszenko M, Lang F, Wieder T, Bosman GJ: The impact of erythrocyte age on eryptosis. Br J Haematol 2012;157:606-614.

-28 Ghashghaeinia M, Toulany M, Saki M, Bobbala D, Fehrenbacher B, Rupec R, Rodemann HP, Ghoreschi K, Rocken M, Schaller M, Lang F, Wieder T: The NFkB pathway inhibitors Bay 11-7082 and parthenolide induce programmed cell death in anucleated Erythrocytes. Cell Physiol Biochem 2011;27:45-54.

29 Jilani K, Lupescu A, Zbidah M, Abed M, Shaik N, Lang F: Enhanced Apoptotic Death of Erythrocytes Induced by the Mycotoxin Ochratoxin A. Kidney Blood Press Res 2012;36:107-118.

30 Jilani K, Lupescu A, Zbidah M, Shaik N, Lang F: Withaferin A-stimulated Ca(2+) entry, ceramide formation and suicidal death of erythrocytes. Toxicol In Vitro 2013;27:52-58.

31 Kucherenko YV, Lang F: Inhibitory Effect of Furosemide on Non-Selective Voltage-Independent Cation Channels in Human Erythrocytes. Cell Physiol Biochem 2012;30:863-875.

-32 Lang E, Qadri SM, Jilani K, Zelenak C, Lupescu A, Schleicher E, Lang F: Carbon monoxide-sensitive apoptotic death of erythrocytes. Basic Clin Pharmacol Toxicol 2012;111:348-355.

33 Lupescu A, Jilani K, Zbidah M, Lang F: Induction of apoptotic erythrocyte death by rotenone. Toxicology 2012;300:132-137.

-34 Polak-Jonkisz D, Purzyc L: Ca Influx versus Efflux during Eryptosis in Uremic Erythrocytes. Blood Purif 2012;34:209-210.

-35 Qadri SM, Bauer J, Zelenak C, Mahmud H, Kucherenko Y, Lee SH, Ferlinz K, Lang F: Sphingosine but not sphingosine-1-phosphate stimulates suicidal erythrocyte death. Cell Physiol Biochem 2011;28:339-346.

-36 Qadri SM, Kucherenko Y, Lang F: Beauvericin induced erythrocyte cell membrane scrambling. Toxicology 2011;283:24-31.

-37 Qadri SM, Kucherenko Y, Zelenak C, Jilani K, Lang E, Lang F: Dicoumarol activates Ca2+-permeable cation channels triggering erythrocyte cell membrane scrambling. Cell Physiol Biochem 2011;28:857-864.

38 Qian EW, Ge DT, Kong SK: Salidroside protects human erythrocytes against hydrogen peroxide-induced apoptosis. J Nat Prod 2012;75:531-537.

39 Shaik N, Zbidah M, Lang F: Inhibition of $\mathrm{Ca}(2+)$ entry and suicidal erythrocyte death by naringin. Cell Physiol Biochem 2012;30:678-686.

40 Vota DM, Maltaneri RE, Wenker SD, Nesse AB, Vittori DC: Differential erythropoietin action upon cells induced to eryptosis by different agents. Cell Biochem Biophys 2013;65:145-157.

-41 Weiss E, Cytlak UM, Rees DC, Osei A, Gibson JS: Deoxygenation-induced and Ca(2+) dependent phosphatidylserine externalisation in red blood cells from normal individuals and sickle cell patients. Cell Calcium 2012;51:51-56.

$\checkmark 42$ Zappulla D: Environmental stress, erythrocyte dysfunctions, inflammation, and the metabolic syndrome: adaptations to CO2 increases? J Cardiometab Syndr 2008;3:30-34.

43 Zbidah M, Lupescu A, Jilani K, Lang F: Stimulation of suicidal erythrocyte death by fumagillin. Basic Clin Pharmacol Toxicol 2013;112:346-351.

-44 Zbidah M, Lupescu A, Shaik N, Lang F: Gossypol-induced suicidal erythrocyte death. Toxicology 2012;302:101-105.

45 Zelenak C, Pasham V, Jilani K, Tripodi PM, Rosaclerio L, Pathare G, Lupescu A, Faggio C, Qadri SM, Lang F: Tanshinone IIA stimulates erythrocyte phosphatidylserine exposure. Cell Physiol Biochem 2012;30:282294.

46 Lang E, Jilani K, Zelenak C, Pasham V, Bobbala D, Qadri SM, Lang F: Stimulation of suicidal erythrocyte death by benzethonium. Cell Physiol Biochem 2011;28:347-354.

-47 Calderon-Salinas JV, Munoz-Reyes EG, Guerrero-Romero JF, Rodriguez-Moran M, Bracho-Riquelme RL, Carrera-Gracia MA, Quintanar-Escorza MA: Eryptosis and oxidative damage in type 2 diabetic mellitus patients with chronic kidney disease. Mol Cell Biochem 2011;357:171-179.

-48 Qadri SM, Mahmud H, Lang E, Gu S, Bobbala D, Zelenak C, Jilani K, Siegfried A, Foller M, Lang F: Enhanced suicidal erythrocyte death in mice carrying a loss-of-function mutation of the adenomatous polyposis coli gene. J Cell Mol Med 2012;16:1085-1093.

49 Sato K, Obinata K, Sugawara T, Urabe I, Yomo T: Quantification of structural properties of cell-sized individual liposomes by flow cytometry. J Biosci Bioeng 2006;102:171-178. 
50 Kempe DS, Lang PA, Eisele K, Klarl BA, Wieder T, Huber SM, Duranton C, Lang F: Stimulation of erythrocyte phosphatidylserine exposure by lead ions. Am J Physiol Cell Physiol 2005;288:C396-402.

51 Mauclere-Denost S, Leboulleux S, Borget I, Paci A, Young J, Al Ghuzlan A, Deandreis D, Drouard L, Tabarin A, Chanson P, Schlumberger M, Baudin E: High-dose mitotane strategy in adrenocortical carcinoma: prospective analysis of plasma mitotane measurement during the first 3 months of follow-up. Eur J Endocrinol 2012;166:261-268.

52 Bookchin RM, Ortiz OE, Lew VL: Activation of calcium-dependent potassium channels in deoxygenated sickled red cells. Prog Clin Biol Res 1987;240:193-200.

53 Fields SZ, Parshad S, Anne M, Raftopoulos H, Alexander MJ, Sherman ML, Laadem A, Sung V, Terpos E: Activin receptor antagonists for cancer-related anemia and bone disease. Expert Opin Investig Drugs 2013;22:87-101.

54 Borst O, Abed M, Alesutan I, Towhid ST, Qadri SM, Foller M, Gawaz M, Lang F: Dynamic adhesion of eryptotic erythrocytes to endothelial cells via CXCL16/SR-PSOX. Am J Physiol Cell Physiol 2012;302:C644-C651.

55 Andrews DA, Low PS: Role of red blood cells in thrombosis. Curr Opin Hematol 1999;6:76-82.

56 Closse C, Dachary-Prigent J, Boisseau MR: Phosphatidylserine-related adhesion of human erythrocytes to vascular endothelium. Br J Haematol 1999;107:300-302.

57 Gallagher PG, Chang SH, Rettig MP, Neely JE, Hillery CA, Smith BD, Low PS: Altered erythrocyte endothelial adherence and membrane phospholipid asymmetry in hereditary hydrocytosis. Blood 2003;101:46254627.

58 Pandolfi A, Di Pietro N, Sirolli V, Giardinelli A, Di Silvestre S, Amoroso L, Di Tomo P, Capani F, Consoli A, Bonomini M: Mechanisms of uremic erythrocyte-induced adhesion of human monocytes to cultured endothelial cells. J Cell Physiol 2007;213:699-709.

59 Wood BL, Gibson DF, Tait JF: Increased erythrocyte phosphatidylserine exposure in sickle cell disease: flowcytometric measurement and clinical associations. Blood 1996;88:1873-1880.

60 Chung SM, Bae ON, Lim KM, Noh JY, Lee MY, Jung YS, Chung JH: Lysophosphatidic acid induces thrombogenic activity through phosphatidylserine exposure and procoagulant microvesicle generation in human erythrocytes. Arterioscler Thromb Vasc Biol 2007;27:414-421.

61 Zwaal RF, Comfurius P, Bevers EM: Surface exposure of phosphatidylserine in pathological cells. Cell Mol Life Sci 2005;62:971-988. 